\title{
The 2015 National Elections in Switzerland : Renewed polarization and shift to the right
}

Daniel Bochsler, Marlène Gerber, David Zumbach

**Accepted version of the paper published in Regional and Federal Studies 26(1): 95-106.**

The 2015 election to the Swiss Parliament denote a return to an already observed trend that was only interrupted in 2011: a shift to the right and an increase in polarization. The vote share of the nationalist-conservative Swiss People's Party (SVP) now reaches a historical height of $29.4 \%$ (+2.8). This note discusses why cantons matter in the Swiss national elections, and to what degree elections have become nationalised. Institutionally, the 26 cantons serve as electoral districts. This leads to a highly disproportional electoral system, and has magnified the minor vote shifts to a slightly more pronounced shift in seats, with the right now holding a tiny majority of 101 of 200 seats in the First Chamber. The two winners, the SVP and the Liberals, had also most campaign funds at disposal. They were able to guide an extensive nationwide campaign where they advocated their core issues instead of candidates. Other parties only advertised at the cantonal level. 


\section{Introduction}

Switzerland has just experienced one of the most stable elections, even by Swiss standards, with net volatility of just over $4 \%$ of the votes. Nevertheless, the elections are perceived as a major shift in the political landscape, with repercussion on the formation of voting majorities in the Swiss parliament, and the elections have been followed by a reshuffling of the partisan composition of the government, a very rare occurrence in Switzerland.

In the very fragmented, but stable Swiss party system ( 5 effective parties in parliament), vote shifts occur mostly within political blocs, whereas shifts between the left and the right are less pronounced. This time, the right could make considerable gains of 15 seats in the lower house (National Council), where it now counts 101 out of 200 seats. The main winner of the 18 October was the national conservative Swiss People's Party (SVP), increasing their vote share from $26.6 \%$ to $29.4 \%(+2.8 \%)$. Within 25 years, the party could move from the fourth-largest party in Switzerland and junior partner in the four-party government to the uncontested leader.

Their majority in the National Council is, though, counterbalanced by the Council of States, where (almost) all cantons are equally represented, and where the mainly majoritarian electoral system has preserved political stability.

This note discusses the electoral rules, the election results, the campaign, and the formation of the government in the Swiss national elections 2015. Hereby, we place particular emphasis on the role of the Swiss cantons in the elections, and the role of the territory.

\section{Electoral rules}

Switzerland has a bicameral legislature. While the two chambers have perfectly equal rights, they are elected differently. The election result reveals the disproportionalities of the electoral rules in both chambers.

The election rules to the National Council, although on first view proportional, contain several elements which are widely distorting the results, usually in favour of large parties, or parties with important regional strongholds: national parliamentary elections in Switzerland are conducted in the 26 cantons, which differ importantly in their size, ranging from 16.000 inhabitants (Appenzell Innerrhoden) to 1.4 million (Zurich), and so does district magnitude. The six smallest cantons send only one MP to the lower house, and elections are conducted under the first-past-the-post vote, often lacking significant competition - occasionally, only 
tacit elections take place - and keeping turnout at a very low level. 20 cantons elect in multimember districts, but only seven of these occupy 10 seats or more, with the maximum being 35 seats in Zurich (Lutz \& Selb, 2007). The vote-seat translation occurs in each of the 20 districts according to proportional representation under the D'Hondt rule. Also, there is no mechanism (e.g. compensation seats) whatsoever, which would reduce the resulting disproportionalities in favour of large parties. In electoral districts with two or more seats, list apparentments allow political parties to link their lists. Such allied lists count as a unit in the first step of the seat allocation, which bear advantages in terms of vote-seat translation (Bochsler, 2010). In the 2015 elections, the main beneficiaries were the Christian Democrats, who allied with smaller parties of the centre-right, and the Social Democrats, who formed alliances with the Green party.

The Council of States, in turn, is composed of an equal number of two representatives for the twenty full cantons, while six (half-)cantons for historical reasons - they have split centuries ago - only send one member to the Council. The cantons are autonomous in deciding on the electoral rules. In 25 out of 26 cantons, the deputies are elected by two-round majority rule.

\section{Election results and territorial variance}

The rise of the Swiss People's Party was closely linked to a programmatic and territorial transformation of the party: programmatically, the party could profit from the new cultural conflict in Swiss politics, on the second issue dimension. Since the late 1980s, the earlier centrist party of farmers and smallholders has gradually taken the leadership of a new nationalist-conservative pole, which is opposed to integration, migration, and globalisation, and defends traditionalist cultural values (Kriesi et al., 2006; Bornschier, 2015). Until the 1990s, the party was only present in protestant and agricultural cantons, while strongest in the German-speaking parts of the country. The transformation to a new nationalist-conservative party of the right was led by the Zurich cantonal branch of the party. Furthermore, the transformation included the formation of new cantonal branches in catholic cantons (where the party was previously not present), intense internal struggles and the re-orientation of traditional cantonal branches, and since the 2000s the move towards the French-speaking cantons. In the French-, and especially the Italian-speaking parts, the party so far operates with less success, and also in the most recent elections, its main gains can be attributed to the German-speaking cantons. The French-speaking areas have held a somehow more favourable view of cantonal electorates to European Integration (although the differences between the linguistic regions have declined). Also, in Ticino (where most Italian speakers live) and in 
Geneva (one of the six French-speaking cantons) many positions of the Swiss People's Party are represented by the 'Lega dei Ticinesi' and the 'Mouvement citoyens genevois', which operate mainly at the cantonal level. However, except for the somehow lower ratings of the SVP in the French- and Italian-speaking parts, the party has a widely nationalised electorate. After the last moderate resorts of the traditional party have split and formed the new BDP in 2008 (see below), the party takes countrywide largely homogeneous positions.

On the long-run, the Swiss People's Party threatens the predominance of the Christian Democrats (CVP) in their traditional Catholic strongholds. At the voting ballot, issues of the Swiss People's Party could already gain considerable support from the rather rural and conservative Catholic regions. With new branches that popped up, the party has eroded deeply into the Christian Democratic basis. The Christian Democrats remain a party which gains most of its support from its traditional (but diminishing) strongholds (Bochsler, 2013; Bühlmann \& Gerber, 2015). In the 2015 elections, its votes have declined, reaching a historical low of $11.6 \%$ in the 2015 elections $(-0.7 \%)$. However, they only lost one seat, while the Socialists (SP) stagnated ( $+0.1 \%$ votes), but lost 3 seats.

The main losers of the elections were, however, two parties, which have recently emerged, and the Greens. The Greens (-1.3\%), continuing their decline since 2011, have lost votes almost in all cantons, resulting in the loss of 4 out of their 14 seats. Two small new parties, the Bourgeois Democratic Party (BDP) and the Green Liberals (GLP) suffered losses of $1.3 \%$ and $0.8 \%$, the latter losing 5 out of 12 seats in parliament. These smaller parties keep a less homogeneous representation throughout the country. The Green Liberals an economic right-wing, but ecological party are represented almost exclusively in rather urbanised cantons of the German-speaking part. The BDP, a moderate split-off of the SVP, is present in protestant, rather rural, and German-speaking cantons. The Green party has a wider territorial coverage, but faces difficulties in several small cantons, especially where restrictive electoral systems for national and cantonal elections reduce competition mainly on the largest parties (Selb \& Pituctin, 2010).

The Liberal Party (FDP) could stop its decline, which has lasted for 36 years, and increased $1.3 \%$ votes ( +3 seats). In the first chamber, the National Council, the economic conservative FDP and the nationalist-conservative SVP (jointly with two tiny parties of this camp) now occupy a razor-thin majority of 101 out of 200 seats. Together with the Social Democrats, the Liberals display historically a rather nationalised structure of their electorate. Overall, with the decline of the Christian Democrats and the nationalisation of the Swiss People's Party, 
territorial variance in Swiss elections has declined in the past decades, but remained roughly stable since 2011 (Bochsler, Mueller, \& Bernauer, forthcoming).

Despite the major shifts in the first chamber, the composition of the second chamber remained rather stable. The Christian Democrats and the Liberals (FDP) keep their strong representation, with 13 seats (out of 46) each. With 12 seats, the Social Democrats (SP) are stronger represented than ever. In the last decades, the SP could profit from increasing divergences within the centre-right: in most cantons, parties of the centre-right no longer present a united front, making it easier for the Social Democrats to capture seats even in cantons where the left is a clear minority. Instead, the SVP does hard in converting its voting potential into mandates under majoritarian election rules (Bochsler \& Bousbah, 2015). As after the elections 2011, the SVP sends 5 representatives to the Council of States.

\section{Electoral Campaign}

The electoral campaign 2015 was dominated by the course of the SVP, who not only trumped most of their rivals in terms of national campaign coordination but also in terms of agenda setting and, supposedly, in terms of financial resources.

\section{Nationalization of electoral campaigning}

Two innovations of electoral campaigning are particularly noteworthy in the framework of the 2015 electoral campaign. On the one hand, the Social Democrats started a large-scale telephone campaign in order to mobilize potential voters. Although new to Switzerland, such strategies are already well-known elsewhere, most prominently in the U.S. On the other hand, the Swiss People's Party engaged in a costly music video production in order to launch a campaign song, starring their most prominent party exponents. These occurrences also highlight the ongoing professionalization and consolidation of national campaign headquarters and the request for unitary appearance (Bühlmann, Gerber, \& Zumbach, forthcoming; see also Bailer \& Bütikofer, 2015).

Unity was further displayed by the Swiss People's Party (SVP) and the Liberals who both guided extensive nationwide campaigns in print media, whereby they advocated their core issues and positions instead of candidates. While the SVP already extensively pursued this 
strategy in the 2011 elections, it is rather new to the FDP. ${ }^{1}$ As Figure 1 shows, it was first and foremost the SVP who extended its national campaign also to the French and Italian part of Switzerland, attempting to gain more ground outside of its traditional voter base. In line with their recent programmatic change (Kriesi et al., 2006; Bornschier, 2015), nine in ten national ads of the Swiss People's Party referred to the issue of immigration and/or asylum. Furthermore, almost half of their ads promoted an anti-EU-stance. In its national campaign ads, the FDP mainly promoted liberal values and to a lesser extent also broached the issue of bilateral agreements with the EU - foremost at the beginning of its campaign, and overall on about $10 \%$ of their national campaign ads. However, the increasing professionalization of campaign activities did not in all cases lead to a nationalization of electoral campaigns. The Christian Democrats, the Social Democrats and the Greens, on the other hand, almost entirely abstained from placing national party ads in newspapers and nearly exclusively carried their candidates. This was different in 2011, where national ads mounted to almost $10 \%$ of all ads

promoting the CVP or the SP. ${ }^{2}$ The difference was most pronounced for the Christian Democrats: while in 2011, the CVP made family policy to the core issue of its national campaign, the issue was largely absent in the 2015 newspaper ads, since individual candidates hardly brought it up.

Figure 1: Distribution of national campaign ads across language region

\footnotetext{
${ }^{1}$ In the forefront of the 2015 elections, one quarter of all gathered newspaper advertisements of the Liberals are national campaign ads. For the SVP, this number mounts to almost one third (APS 2015).

${ }^{2}$ Already in 2011, the Greens concentrated on cantonal ads, i.e. almost exclusively carried candidates and their positions.
} 


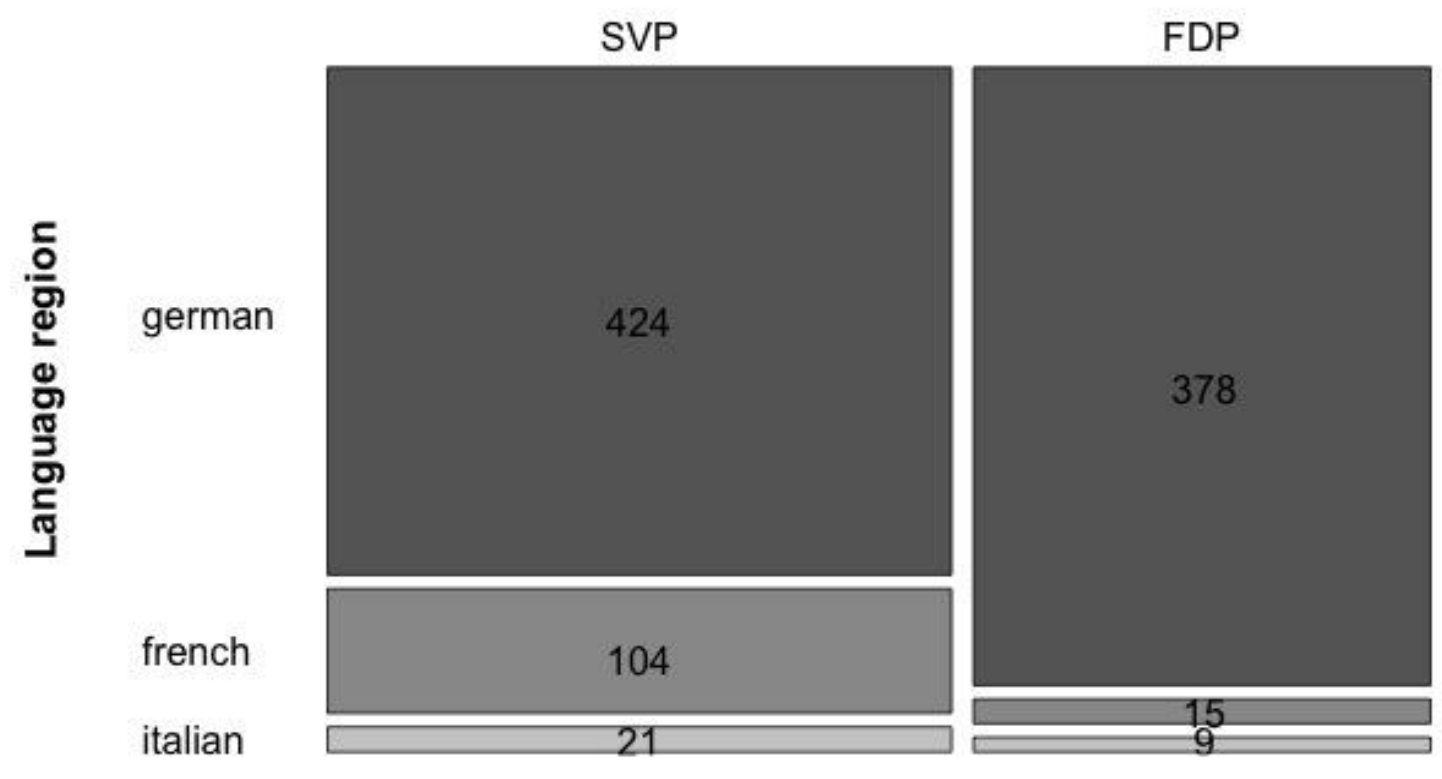

Notes: Entries reflect the total amount of collected national campaign ads in 50 important national and regional newspapers (APS 2015). Contrary to cantonal ads where candidates and their positions are on display, national ads aim at advancing one or several core issues of a party. In the 2015 elections, the FDP and the SVP were the only parties who conducted an extensive nationwide campaign.

The two newcomer parties, the Green Liberals and the BDP, conducted a selective campaign in different cantons and regions: The parties' campaign intensity varied more strongly between the cantons than in the previous elections. This, and the concentration of their newspaper advertisements in fewer cantons compared to 2011, corroborates the assumption that both parties continue to concentrate on a rather narrow voter segment, which can be found in selected regions only.

\section{Campaign topics}

Besides the SVP who opposed migration, refugees and EU integration, the Liberals and the Social Democrats focused on their core issues economy and social welfare, respectively. So did the Christian Democrats by bringing family policies on the agenda (although less visible than in 2011, see above), but also several economic issues. The Greens focused on their core issue, ecology, and on asylum policy. In doing so, they were the only ones countering the hard line of the Swiss People's Party on this subject. The Bourgeois Democratic Party (BDP) advocated reforms in the energy sector, in order to increase the production of non-nuclear electric power, the advancement of women and the Bilateral Treaties with the EU. The Green Liberals (GLP) aimed at both, a strong economy and strong environmental protection. However, supposedly due to financial constraints (see also Figure 4), the campaigns of the 
Greens, the BDP and in particular the GLP were rather invisible. Also in the media, the two newcomer parties do not receive essential attention, as Figure 2 shows.

\section{Figure 2: The presence of parties in the Swiss online media}

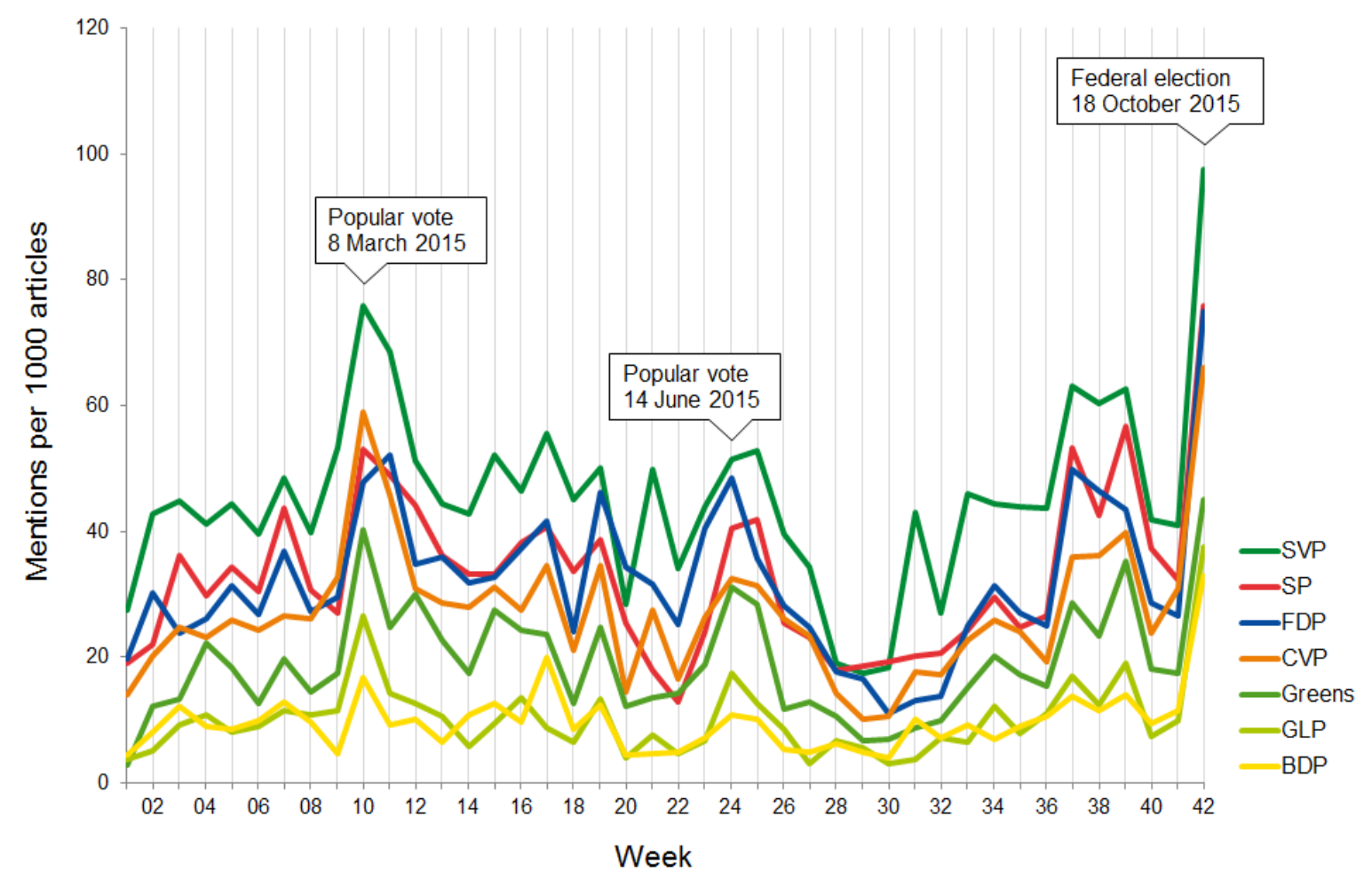

On the other hand, the electoral campaign 2015 was considered to be a campaign without content. Policies were more present in the 2011 elections, when no commercial campaign song was produced and almost every party pursued its own popular initiative in order to advance one of their core topics. ${ }^{3}$ However, given that besides the initiative of the Swiss People's Party all initiatives were rejected at the ballot or even failed at the stage of signature collection, this change in strategy may be comprehensible. The implementation of the SVP's “initiative against mass immigration", accepted in February 2014 by a narrow majority of $50.3 \%$ of the voters and 17 out of 26 cantons, is still pending. Since the initiative aims at restricting immigration in Switzerland, the Federal Council is assigned to renegotiate the Agreement on the Free movement of Persons with the EU in order to implement it - a still ongoing process. Given the significance of the Bilateral Agreements for Switzerland and the high news value of the initiative and its potential consequences (see Bühlmann, Gerber, \&

\footnotetext{
${ }^{3}$ In case of the FDP, this was the initiative against more state intervention. With their initiative, the SP advocated the introduction of a minimum wage, the CVP opted for easing the tax burden for families, the SVP launched their initiative against mass immigration and the Green Liberals wanted to introduce an energy tax. The BDP and the Greens did not initiate popular initiatives, but the Greens widely spread their message against nuclear energy.
} 
Zumbach, 2015), it is surprising how little the relation with the EU has been brought up by the other parties in the run-up to the elections. Data of political advertisements in more than 50 important daily and weekly national and regional newspapers (APS, 2015) show that besides the SVP, basically only the Liberal Party took up the issue (in $7.8 \%$ of all their ads). Yet this was different in the canton of Ticino, where the 'Lega dei Ticinesi', a regionalist party with an anti-immigration and anti-EU platform, was - contrary to the 2011 elections - heading in terms of the number of party advertisements: more than one in five of their collected ads $(\mathrm{N}=74)$ contained positions against the EU or positions favoring immigration restrictions. ${ }^{4}$ This is why these topics were, altogether, more present in the Italian speaking part of Switzerland than elsewhere, as Figure 3 shows. The Liberals concentrated their national political ads in the German-speaking media, in order to counterbalance equivalent ads of the SVP (see Figure 1). Therefore, the French-speaking region exhibits a higher share of ads broaching the issues of asylum, migration and EU than the German-speaking region does.

\section{Figure 3: Linguistic regional variation in campaign topics}

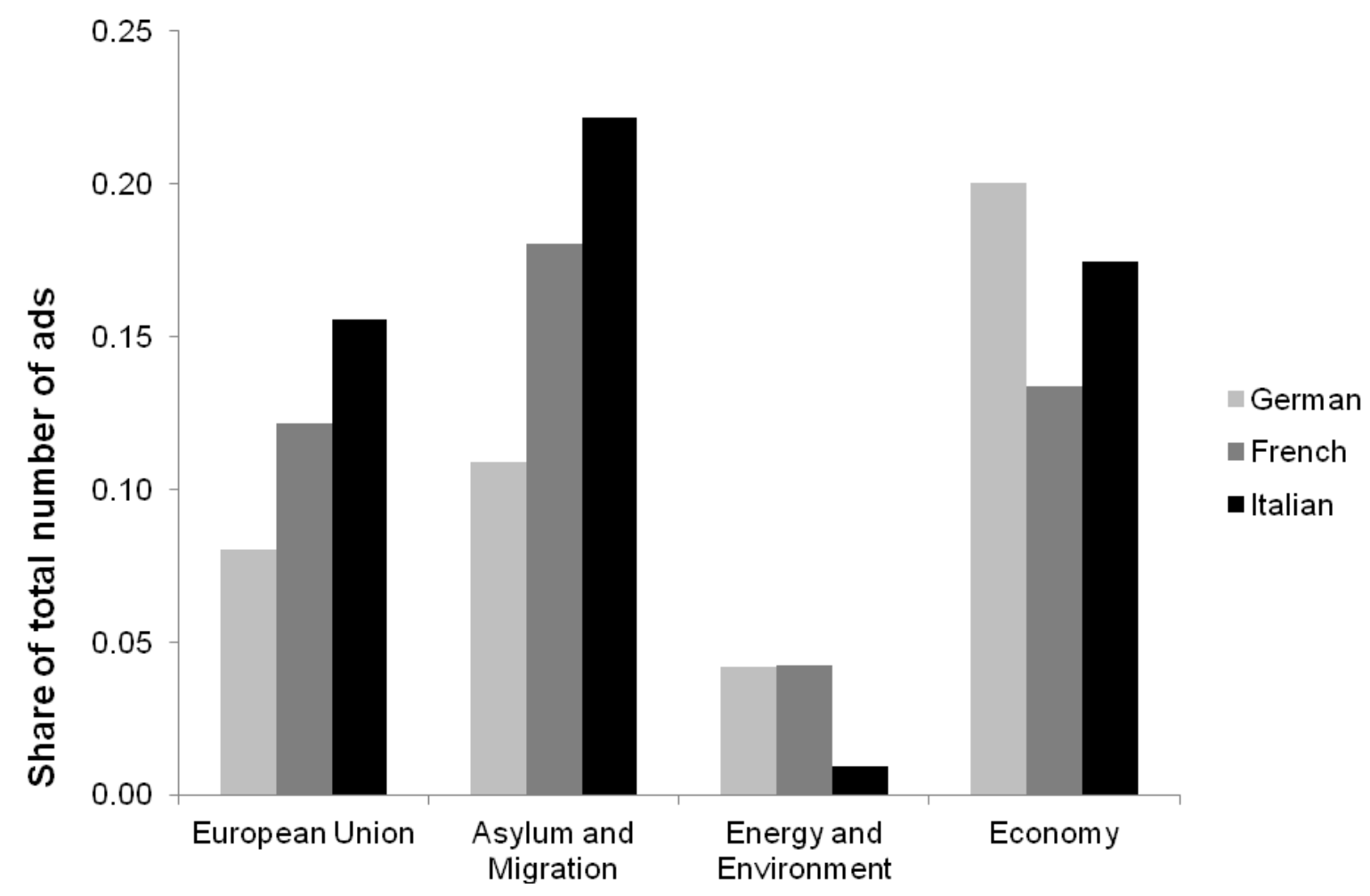

\footnotetext{
${ }^{4}$ The same accounts for the regionalist party in Geneva, the 'Mouvement citoyens genevois'. However, campaign intensity in terms of newspaper advertisements was rather low, which is why we refrain from drawing more definite conclusions.
} 
Notes: Entries reflect the percentage share of ads in a linguistic region that broach a given campaign topic (APS 2015). Up to four topics per political ad were coded. In all regions, slightly more than $50 \%$ of the ads did not contain a topic.

\section{Pronounced inequalities in campaign financing}

The campaign 2015 was probably the most expensive campaign ever, rendering this likely circumstance - together with pronounced inequalities in campaign funding - itself to a political issue. Estimations for the period from 2008 to 2011 suggest that there are very pronounced inequalities in the funding of election and referendum campaigns between the parties (Hermann, 2012: 34). As Figure 4 shows, electoral campaigning in terms of political advertisement placed in print media was also unequally distributed in 2015: the Liberals and the Swiss People's Party accounted for about 30\% of all published newspaper ads each. Compared to the 2011 elections, the increase in ads is particularly noteworthy for the Liberals, while the Christian Democrats and the leftist parties published slightly less ads (APS, 2011, 2015), thus slightly increasing existing inequalities in electoral campaigning.

\section{Figure 4: Amount of ads per party and language region}

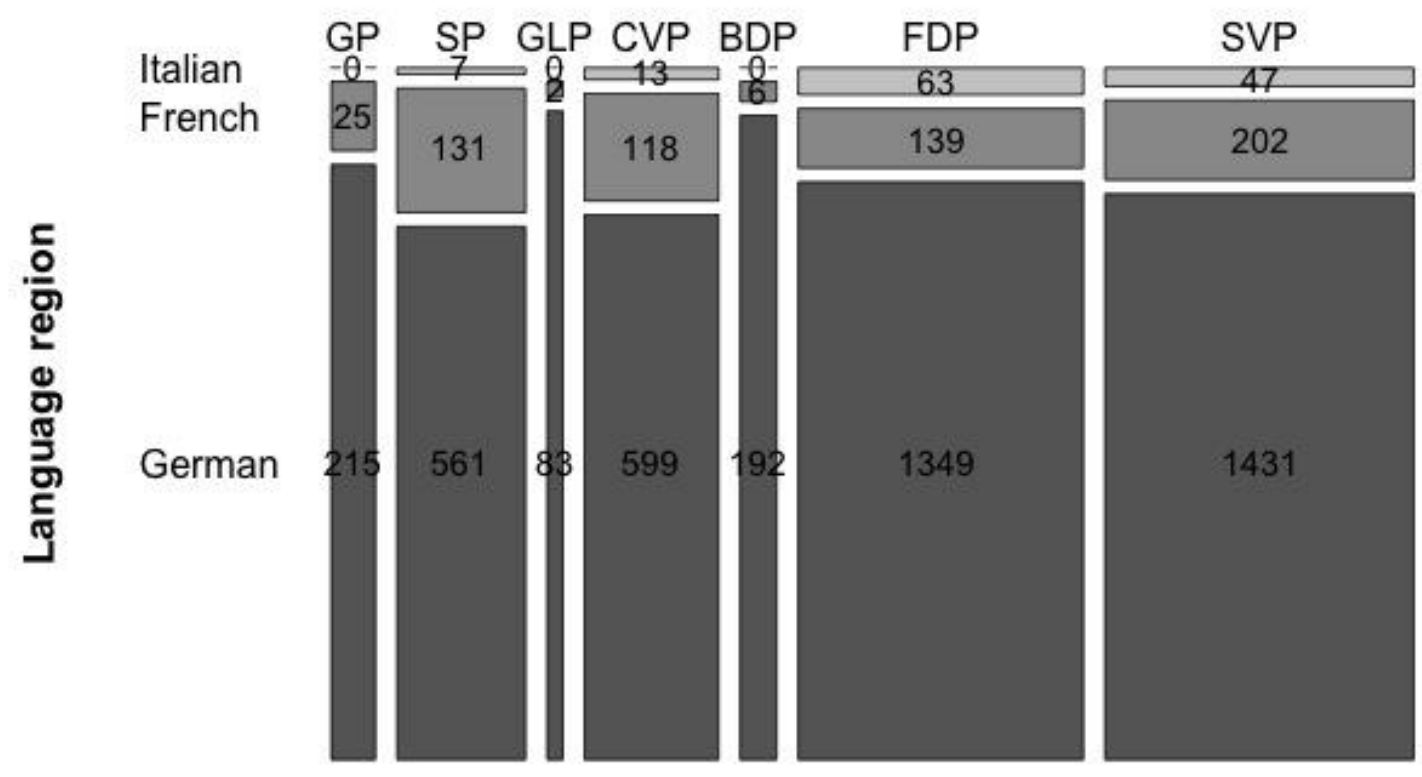

Notes: Entries reflect the total amount of collected national and cantonal campaign ads of the seven major parties in the forefront of the parliamentary elections of $18^{\text {th }}$ October 2015. Political ads were collected in 50 important national and regional newspapers since the beginning of the election year (APS 2015). 
Switzerland is one of the last remaining European countries that do not require parties to disclose their campaign funding and this is why the country has repeatedly been criticized by the OSCE (2012) and the Council of Europe (Greco, 2011, 2014). Within the Parliament, several attempts have been undertaken - mostly by the not-so-wealthy Left - to change this situation. However, neither the majority in parliament nor in government was willing to push on this issue. The government justified its position with the peculiarities of the Swiss system, i.e. the pronounced direct democracy bringing also other actors than the political parties onto the stage, the strong federalism not wanting to interfere in cantonal matters, as well as the continuing perception that politics should be conducted by non-professionals (Der Bundesrat, 2014).

\section{Government formation}

The government consists of seven ministers, and is elected in a joint meeting of the two houses of parliament in early December after the elections. Each minister is elected in a single vote, by multi-round majority rule. Since 1943, and then again since 1959 after a six-year interruption, the four largest parties have shared the seats in government, although the government clearly differs from a common coalition government, since there is no coalition program. The government formula grants one seat to the Swiss People's Party and two seats to the Christian Democrats, the Liberals and the Social Democrats each (Altermatt, 2012). This formula was first abrogated in 2003 when a second member of the SVP got elected as Federal Councilor, at the expense of a Christian Democrat.

For the first time after 1959, the partisan composition of the of the government became an issue after the rise of the SVP in parliamentary elections in the mid to late 1990s. The debate was fuelled by partisan calculations and interpretations of informal rules about proportional representation in government, usually both mathematically faulty and historically inappropriate. The election of a non-official candidate, Evelyne Widmer-Schlumpf, from the ranks of the SVP in 2007 has even lead to a subsequent expulsion of both SVP ministers and a cantonal party branch from the party, resulting in the establishment of the BDP (see above) and leaving the SVP, after a short time of opposition, again with one seat in government. After the electoral shifts in 2015, and after the Liberals announced their will to replace Widmer-Schlumpf (BDP) with a minister from the ranks of the SVP, she stepped back from office. In the elections of 9 December, the SVP managed with a quite unusual level of political threat to convince the other parties to select one of the official party nominees, so that the largest party is back with two seats in the government. For the first time, the party 
stands with the winemaker Guy Parmelin (VD) a minister from the French-speaking part of the country, although the candidate was largely perceived as an inexperienced tactical candidate, who should smooth the way to a controversial candidate from the financial centre and tax haven Zug, the business consultant Thomas Aeschi, to the Federal Council (Stojanović \& Giudici, forthcoming). If the move was indeed tactical, then it failed. In any case, it helped to shift the regional-language balance in favor of the linguistic minorities.

\section{Discussion: Back to normal?}

After the 2015 elections, the key question is how the SVP will react to its strengthened representation in the National Council and in the government. Will Switzerland return to a model of consociational decision-making, as it was characterised until the 1990s (see also Bochsler, Häusermann, \& Hänggli, 2015 for a broader discussion). There are two important caveats. First, we face a split parliament: while the right holds a tiny majority in the National Council, the left and the Christian Democrats keep a narrow majority in the Council of States. This taken together with the constant referendum threat might hamper consensus finding in the new legislature. Second, based on past experiences - there were previous attempts to further engage the party in the institutions - and current signals, there is no indication that the SVP would aspire to restore a system of broad elite compromises. However, the SVP alone does not have a quorum and needs to rely on other parties to legislate. Thus, a system of situational coalitions i.e. coalitions that change according to policy-fields (Traber, 2015), might be maintained.

\section{The contributors}

Daniel Bochsler (PhD, University of Geneva) is Assistant Professor of Comparative Politics and Democratisation at the University of Zurich. He works on ethnic politics, elections, and democratisation.

Marlène Gerber ( $\mathrm{PhD}$, University of Bern) is Deputy Director of the Swiss Political Yearbook (Année Politique Suisse) at the University of Berne. Her research interests include deliberation, direct democracy, and political communication.

David Zumbach is Research Assistant at the University of Bern and writes for the Swiss Political Yearbook. His research focuses on Swiss economic policies, political competition, and voting behavior. 


\section{Bibliography}

Altermatt, Urs (2012) Zwischen katholischem Milieu und bürgerlicher Mittepartei: Das Historische Dilemma der CVP. Baden: Hier + Jetzt.

APS (2011) Database: Political advertisements in the 2011 Federal Elections. Bern: Année Politique Suisse.

APS (2015) Database: Political advertisements in the 2015 Federal Elections. Bern: Année Politique Suisse.

Bailer, Stefanie and Sarah Bütikofer (2015) 'From Loose Alliances to Professional Political Players: How Swiss Party Groups Changed', Swiss Political Science Review 21(4): 556-577.

Bochsler, Daniel (2010) 'Who gains from apparentments under D'Hondt?', Electoral Studies 29(4): 617-627.

Bochsler, Daniel (2013, 5 March) Die CVP verliert das Wallis und das Ständemehr. Neue Zürcher Zeitung, p. 9.

Bochsler, Daniel and Karima Bousbah (2015) 'Competitive Consensus: What comes after consociationalism in Switzerland?', Swiss Political Science Review.

Bochsler, Daniel, Silja Häusermann and Regula Hänggli (2015) 'Consensus lost? Disenchanted democracy in Switzerland', Swiss Political Science Review.

Bochsler, Daniel, Sean Mueller and Julian Bernauer (forthcoming) 'An Ever Closer Union? The Nationalisation of Political Parties in Switzerland, 1991-2015', Swiss Political Science Review.

Bornschier, Simon (2015) 'The New Cultural Conflict, Polarization, and Representation in the Swiss Party System, 1975-2011', Swiss Political Science Review 21(4): 680-701.

Bühlmann, Marc and Marlène Gerber (2015) 'Von der Unterschichtspartei zur Partei des gehobenen Mittelstands? Stabilität und Wandel der Wählerschaften der Sozialdemokraten und anderer grosser Schweizer Parteien zwischen 1971 und 2011', in Markus Freitag and Adrian Vatter (eds.) Wahlen und Wählerschaft in der Schweiz (pp. 71-94). Zürich: NZZ.

Bühlmann, Marc, Marlène Gerber and David Zumbach. (2015). Wahlkampf 2015: Die Parteien in den Medien. Newsletter 38, from http://chronik-on.eurospider.com/chronik-onnewsletter.20151016.html

Bühlmann, Marc, Marlène Gerber and David Zumbach (forthcoming) 'Campaign Strategies at the Swiss National Elections 2015', Swiss Political Science Review.

Der Bundesrat (2014, 12 November) Parteienfinanzierung wird nicht gesetzlich geregelt. Media release of the Federal Council.

Greco (2011) Evaluation Report on Switzerland: Transparency of Political Party Funding: Group of States against corruption.

Greco (2014) Interim Compliance Report on Switzerland: Incriminations, Transparency of Party Funding: Group of States against corruption.

Hermann, Michael (2012) Das politische Profil des Geldes: Wahl- und Abstimmungswerbung in der Schweiz. Zürich: Sotomo.

Kriesi, Hanspeter, Edgar Grande, Romain Lachat, Martin Dolezal, Simon Bornschier and Tim Frey (2006) 'Globalization and the Transformation of the National Political Space: Six European Countries Compared', European Journal of Political Research 45(6): 921-957.

Lutz, Georg and Peter Selb (2007) 'The National Elections in Switzerland', in Ulrich Klöti, Peter Knoepfel, Hanspeter Kriesi, Wolf Linder, Yannis Papadopoulos and Pascal Sciarini (eds.) Handbook of Swiss Politics (pp. 405-434). Zurich: NZZ.

OSCE ODIHR (2012) Switzerland, Federal Elections, 23 October 2011: Final Report. Warsaw: Organization for Security and Co-operation in Europe.

Selb, Peter and Sandrine Pituctin (2010) 'Some Methodological Issues in the Study of New Parties Entry and Electoral Success', Party Politics 15. 
Stojanović, Nenad and Anja Giudici (forthcoming) 'Party, regional and linguistic proportionality under majoritarian rules: The 2015 elections to the Federal Council', Swiss Political Science Review.

Traber, Denise (2015) 'Disenchanted Swiss Parliament? Electoral Strategies and Coalition Formation', Swiss Political Science Review. 